\title{
Assessment of Heavy Metal Levels in Street Dust Samples from Denizli, Turkey, and Analysis by Flame Atomic Absorption Spectrometry
}

\author{
Abdullah Akdogan ${ }^{a}$, Umit Divriklia*, Mustafa Soylak ${ }^{\text {b* }}$, and Latif Elci ${ }^{\mathrm{a}}$ \\ a Pamukkale University, Science and Arts Faculty, Department of Chemistry, 20017 Denizli, Turkey \\ b Erciyes University, Fen Faculty, Department of Chemistry, 38039 Kayseri, Turkey
}

\section{INTRODUCT1ON}

Soil, sediments, and dust originate primarily from the earth's crust. However, street dust is also a consequence of the interaction of solid, liquid, gaseous materials and heavy metals produced from sources such as traffic, industry, building construction, heating, solid waste incineration, and other man-made activities, which cause contamination and affect human health. Roadways and automobiles are considered to be one of the largest sources of heavy metals in solid matter (1-5). Heavy metal pollution in environmental samples has been increasing for a long time (6-9) and is due to human activities as well as atmospheric events (1, 10-12).

Street dust samples are an important and easily obtainable source for monitoring environmental pollution (13-16). Traffic in particular is a source of emission of heavy metals such as $\mathrm{Pb}, \mathrm{Ni}, \mathrm{Cd}, \mathrm{Zn}, \mathrm{Mn}$, $\mathrm{Cu}, \mathrm{Co}$, and $\mathrm{Cr}(15,17-20)$. These types of metals are non-degradable and hazardous to human health. A number of studies have been carried out for the determination of trace metals in urban street dust (21-27) in order to obtain the level of heavy metal pollution in certain areas.

In general, when heavy metals are inhaled from street dust and also attach to the skin, they can affect the nervous, blood-forming, cardiovascular, renal, and reproduc-

\footnotetext{
* Corresponding autbor.

E-mail: divrikli@pau.edu.tr and

soylak@erciyes.edu.tr

Tel.: +902582963596
}

\begin{abstract}
In this study, toxic heavy metal contamination in dust samples obtained from different streets in Denizli, Turkey, was monitored. The areas selected include heavy, moderate, and normal traffic flow, building construction sites and other industrial activities near roads, car parks, school gardens, health centers, and hospitals. The metals were determined by flame atomic absorption spectrometry. The concentration ranges were $\mathrm{Cu}$ at 20.4-147.4 $\mu \mathrm{g} \mathrm{g}^{-1}$, Cr at 9.9-75.0 $\mu \mathrm{g} \mathrm{g}^{-1}, \mathrm{Ni}$ at $22.8-86.2 \mu \mathrm{g} \mathrm{g}^{-1}, \mathrm{~Pb}$ at $14.4-145.3 \mu \mathrm{g} \mathrm{g}^{-1}$, and $\mathrm{Mn}$ at 52.3-158.3 $\mu \mathrm{g} \mathrm{g}^{-1}$. The Cd content for all dust samples was below $0.1 \mu \mathrm{g} \mathrm{g}^{-1}$. According to the geoaccumulation index $\left(\mathrm{I}_{\text {geo }}\right)$ classification, $\mathrm{Cr}$ and $\mathrm{Mn}$ were present at the lower level $\left(0<\mathrm{I}_{\text {geo }} \leq 1\right)$, and $\mathrm{Pb}, \mathrm{Cu}$, and $\mathrm{Ni}$ at moderate level $\left(1<\mathrm{I}_{\text {geo }} \leq 2\right)$. This is the fist time that the concentrations and the effect of heavy metals on the environment, in particular, in street dust of Denizli, Turkey, have been investigated.
\end{abstract}

tive systems. Street dust is also mobilized from wind and moving cars. In addition, dust is carried by storm water runoff and contaminates reservoirs, rivers, and the sea. Some trace metals such as $\mathrm{Cu}$ and $\mathrm{Zn}$ are harmless at low levels, but $\mathrm{Pb}$, As, $\mathrm{Hg}$, and $\mathrm{Cd}$ are toxic even at extremely low concentrations (28-34). Thus, the determination of metals in environmental samples such as dust, plants, soil, and surface waters is highly important to assess environmental pollution and to avoid jeopardizing human health (35).
Denizli is in the Aegean part of Turkey and lies at $354 \mathrm{~m}$ above sea level. The highest mountain in the province and in Western Anatolia is Mount Honaz $(2571 \mathrm{~m})$. Though located in the Aegean region, Denizli is not totally affected by the Aegean climate. It is partially dry, but the average humidity is $70 \%$ in the winter months, while in the summer it is $50 \%$. It is an agricultural city with some textile industry. According to the census taken in the year 2000, the city has a population of 850,000 .

To our knowledge, a study for heavy metal levels in street dust samples from Denizli, Turkey, has not before been reported. We investigated the level of metals in street dust samples from different areas of the city using flame atomic absorption spectrometry (FAAS). The correlation between metal concentration in the samples and the geoaccumulation indices was also investigated. Information about the traffic patterns was obtained from the Traffic Department in Denizli.

\section{EXPERIMENTAL}

\section{Instrumentation}

For this study, a PerkinElmer ${ }^{\circledR}$ AAnalyst $^{\text {TM }} 700$ flame atomic absorption spectrometer (PerkinElmer, Inc., Shelton, CT, USA) was used, equipped with a stainless steel nebulizer, deuterium background correction, and hollow cathode lamps (HCL). All measurements were carried out in an air/acetylene flame. The instrumental operating parameters and linear ranges are listed in Table $\mathrm{I}$. 


\section{Reagents and Standard Solutions}

All reagents were of analytical reagent grade unless otherwise stated. Milli-Q ${ }^{\circledR}$ double deionized water (Millipore Corporation, USA, $18.2 \mathrm{M} \Omega{ }^{\bullet} \mathrm{cm}^{-1}$ resistivity) was used for all dilutions. $\mathrm{HNO}_{3}$ and $\mathrm{HCl}$ were of Suprapur ${ }^{\circledR}$ quality (E. Merck, Darmstadt, Germany). All plastic and glassware was cleaned by soaking in dilute $\mathrm{HNO}_{3}(1+9)$ and rinsing with distilled water prior to use. The stock solutions (1000 $\mathrm{mg} \mathrm{L}^{-1}$ ) of the analyte elements were prepared from appropriate amounts of their nitrate salts in 1\% $\mathrm{HNO}_{3}$ and then further diluted daily prior to use.

\section{Sampling}

A total of 59 street dust samples were obtained from areas around hospitals and health centers, school gardens, as well as from areas with heavy, moderate, and normal traffic flow in the Denizli city center. Sample collection was done by sweeping an area of $2 \mathrm{~m}^{2}$ and transferring the sweepings into a polyethylene container. The samples were then passed through a 30-mesh sieve, dried at $110^{\circ} \mathrm{C}$ in NUVE dry-heat sterilizers (NUVE FN 055, Ankara, Turkey) for 20 hours. The control samples were collected from two hills on the outskirts of Denizli.

\section{Sample Preparation}

Each of the 59 samples was digested in triplicate $(\mathrm{N}=3)$. A 0.5-g amount of dust sample was weighed and transferred to a Pyrex ${ }^{\circledR}$ tube, and $10 \mathrm{~mL}$ of aqua regia was added. The sample was transferred to a heating block for 6 hours to complete the digestion. The residue was filtered through a $0.45-\mu \mathrm{m}$ pore size micro filtration system (Millipore Corporation, USA). A 1-g amount of the filtrate combined with the leachate was diluted to $25 \mathrm{~mL}$ with deionized water, and the metal levels were determined by flame atomic absorption spectrometry (FAAS). Blank digestions were also carried out.

\section{Accuracy and Precision}

In order to validate the method for accuracy and precision, a certified reference material NIST CRM 8704 Buffalo River Sediment (National Institute of Standards and Technology, Gaithersburg, MD, USA) was used. The certified concentrations of the studied heavy metals in CRM 8704 Buffalo River Sediment were $2.94 \mathrm{mg} \mathrm{kg}^{-1}, 121.9$ $\mathrm{mg} \mathrm{kg}^{-1}, 544.0 \mathrm{mg} \mathrm{kg}^{-1}, 42.9 \mathrm{mg} \mathrm{kg}^{-1}$ and $150.0 \mathrm{mg} \mathrm{kg}^{-1}$ for $\mathrm{Cd}, \mathrm{Cr}, \mathrm{Mn}$, $\mathrm{Ni}$ and $\mathrm{Pb}$, respectively. The digestion procedure given above was also applied to the CRM 8704 Buffalo River Sediment to determine the recoveries of the analytes and the results are listed in Table II. The samples were analyzed both with and without spiked standards containing a mixture of different amounts of the examined metals. The results in Table II indicate that in the digestion procedure the recovery of the metal ions was generally 95\%. A preliminary test involving six replicate digestions of one dust sample for $\mathrm{Cr}, \mathrm{Pb}, \mathrm{Cu}, \mathrm{Ni}$, $\mathrm{Mn}$, and Cd produced relative standard deviations of about 1.1-6.5\%.

\section{RESULTS AND DISCUSSION}

Analyte elements were chosen as representative metals whose levels in the environment represent a reliable index of hazardous environmental pollution. The minimum and maximum concentrations of the metals found in the street dust samples are listed in Table III. The concentration range of the different metals was as follows: $\mathrm{Cu}$ at 20.4-147.4 $\mu \mathrm{g} \mathrm{g}^{-1}, \mathrm{Cr}$ at 9.9-75.0 $\mu \mathrm{g} \mathrm{\textrm {g } ^ { - 1 }}, \mathrm{Ni}$ at $22.8-86.2 \mu \mathrm{g} \mathrm{g}^{-1}, \mathrm{~Pb}$ at $14.4-145.3 \mu \mathrm{g} \mathrm{g}^{-1}$, and $\mathrm{Mn}$ at 52.3-158.3 $\mu \mathrm{g} \mathrm{g}^{-1}$. The Cd content for all dust samples was found to be below $0.1 \mu \mathrm{g} \mathrm{g}^{-1}$. High traffic areas had the highest heavy metal levels (Figure 1), while the lowest values of the analytes were found in school gardens, except for lead and copper. Concentrations of $\mathrm{Cu}$ and

TABLE I

Instrumental and Operating Conditions Using the AAnalyst 700 FAAS and

Linear Ranges for $\mathrm{Cu}, \mathrm{Cd}, \mathrm{Ni}, \mathrm{Pb}, \mathrm{Cr}$, and $\mathrm{Mn}$

\begin{tabular}{|c|c|c|c|c|c|c|c|c|c|}
\hline \multirow{2}{*}{$\begin{array}{c}\text { Ele- } \\
\text { ments }\end{array}$} & \multirow{2}{*}{$\begin{array}{c}\text { Parameters } \\
\text { Wave- } \\
\text { length } \\
(\mathrm{nm})\end{array}$} & \multirow{2}{*}{$\begin{array}{c}\text { Slit } \\
\text { Width } \\
\text { (nm) }\end{array}$} & \multirow{2}{*}{$\begin{array}{l}\text { Lamp } \\
\text { Current } \\
\text { (mA) }\end{array}$} & \multirow{2}{*}{$\begin{array}{l}\text { Linear } \\
\text { Range } \\
\left(\mu \mathrm{g} \mathrm{mL} L^{-1}\right)\end{array}$} & \multicolumn{3}{|c|}{$\begin{array}{c}\text { Sediment } \\
(\text { CRM 8704) }\end{array}$} & \multicolumn{2}{|c|}{$\begin{array}{c}\text { Street Dust From } \\
\text { Heavy Traffic }\end{array}$} \\
\hline & & & & & $\begin{array}{c}\text { Ele } \\
\text { ments }\end{array}$ & $\begin{array}{c}\text { Recovery } \\
(\%)\end{array}$ & $\begin{array}{l}\text { RSD } \\
(\%)\end{array}$ & $\begin{array}{c}\text { Recovery } \\
(\%)\end{array}$ & $\begin{array}{r}\text { RSD } \\
(\%) \\
\end{array}$ \\
\hline $\mathrm{Cu}$ & 324.8 & 0.7 & 30 & $0.5-4.0$ & $\mathrm{Cr}$ & 95 & 2.5 & 98 & 2.5 \\
\hline $\mathrm{Cd}$ & 228.8 & 0.7 & 4 & $0.1-2.0$ & $\mathrm{~Pb}$ & 98 & 2.9 & 102 & 1.7 \\
\hline $\mathrm{Ni}$ & 232.0 & 0.2 & 30 & $0.5-4.0$ & $\mathrm{Cu}$ & 96 & 6.0 & 97 & 5.7 \\
\hline $\mathrm{Pb}$ & 283.3 & 0.7 & 10 & $2.0-16.0$ & $\mathrm{Ni}$ & 101 & 6.5 & 101 & 1.1 \\
\hline $\mathrm{Cr}$ & 357.9 & 0.7 & 30 & $1.0-6.0$ & Mn & 99 & 1.2 & 101 & 1.5 \\
\hline Mn & 279.5 & 0.2 & 25 & $0.5-4.0$ & $\mathrm{Cd}$ & 104 & 1.7 & 103 & 3.6 \\
\hline
\end{tabular}

RSD (\%): relative standard deviation.

TABLE II

Analytical Performance of Sample Digestion Procedure of Samples $(\mathrm{N}=6)$ 


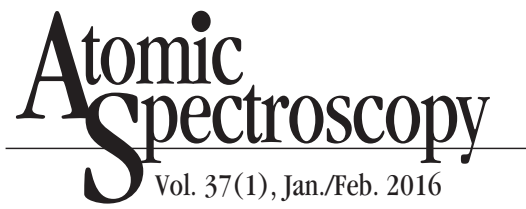

$\mathrm{Pb}$ exhibited a similar pattern. An increased concentration for $\mathrm{Cu}$ and $\mathrm{Pb}$ was observed at locations with high traffic and, to some extent, in the industrial areas. The concentrations of the analytes in all analyzed samples were higher than those in the control samples. The concentrations of the heavy metals in the control samples were as follows: $\mathrm{Cu}$ at $12.4 \pm 0.7 \mu \mathrm{g} \mathrm{g}^{-1}, \mathrm{Cr}$ at $3.1 \pm$ $0.2 \mu \mathrm{g} \mathrm{g}^{-1}$, Ni at $10.7 \pm 0.7 \mu \mathrm{g} \mathrm{g}^{-1}$, $\mathrm{Pb}$ at $8.7 \pm 0.5 \mu \mathrm{g} \mathrm{g}^{-1}$, and $\mathrm{Mn}$ at $21.4 \pm 1.7 \mu \mathrm{g} \mathrm{g}^{-1}$.

The levels of the different analytes in the street dust samples reported for various cities around the world are listed in Table IV. It was found that the chromium levels around Denizli were generally lower than in cities such as Bahrain, Xi'an, Kayseri (1, 3, 36, $37)$. The $\mathrm{Pb}$ concentrations varied greatly from city to city and were from 1.03 to $697 \mu \mathrm{g} \mathrm{g}^{-1}$. The concentration of $\mathrm{Cu}$ varied from 38 to $467 \mu \mathrm{g} \mathrm{g}^{-1}$, Ni from 10 to $128 \mu \mathrm{g} \mathrm{g}^{-1}$. Interestingly, the $\mathrm{Ni}$ concentrations found in this work were lower than the values found by Tuzen in Tokat, Turkey (7). Table IV shows that the highest concentration of $\mathrm{Ni}$ was found in Tokat city. It was a positive sign that the levels of $\mathrm{Mn}$ and $\mathrm{Cd}$ in the investigated areas of Denizli were generally lower than those found in other cities around the world.

The mean levels of the investigated analyte ions are depicted in Figure 1. The maximum allowable concentrations (MAC) as per the Official Gazette of the Republic of Turkey in soil samples are as follows: $50 \mu \mathrm{g} \mathrm{g}^{-1}$ for $\mathrm{Pb}, 1 \mu \mathrm{g} \mathrm{g}^{-1}$ for $\mathrm{Cd}, 100 \mu \mathrm{g} \mathrm{g}^{-1}$ for $\mathrm{Cr}, 50 \mu \mathrm{g} \mathrm{g}^{-1}$ for $\mathrm{Cu}$, and $30 \mu \mathrm{g} \mathrm{g}^{-1}$ for $\mathrm{Ni}$ (38). Thus, the findings of this study show that the $\mathrm{Pb}$ and $\mathrm{Ni}$ levels exceeded the MAC levels in heavy, moderate, and low traffic areas and around the hospitals, while $\mathrm{Cu}$ exceeded in heavy and moderate traffic areas.
TABL̄E III

Descriptive Statistics for Concentrations of Trace Metals in Dust Samples From Denizli, Turkey $\left(\mu \mathrm{g} \mathrm{g}^{-1}\right)$

\begin{tabular}{cccccc}
\hline $\begin{array}{c}\text { Ele- } \\
\text { ments }\end{array}$ & $\begin{array}{c}\text { Minimum } \\
\text { Value }\end{array}$ & $\begin{array}{c}\text { Maximum } \\
\text { Value }\end{array}$ & $\begin{array}{c}\text { Arithmetic } \\
\text { Mean }\end{array}$ & $\begin{array}{c}\text { Standard } \\
\text { Deviation }\end{array}$ & $\begin{array}{c}\text { Soil Back- } \\
\text { ground Conc. }\end{array}$ \\
\hline $\mathrm{Cr}$ & 9.9 & 75.0 & 49.7 & 24.5 & 50 \\
$\mathrm{~Pb}$ & 14.4 & 145.3 & 69.2 & 47.1 & 26 \\
$\mathrm{Cu}$ & 20.4 & 147.4 & 63.0 & 47.2 & 26 \\
$\mathrm{Ni}$ & 22.8 & 86.2 & 44.4 & 25.0 & 18.5 \\
$\mathrm{Mn}$ & 52.3 & 158.3 & 131.0 & 40.7 & 490 \\
$\mathrm{Cd}$ & $<0.1$ & $<0.1$ & - & - & $0.41-0.57$ \\
\hline
\end{tabular}

TABLE IV

Mean Concentration of Heavy Metals $\left(\mu \mathrm{g} \mathrm{g}^{-1}\right)$ in Street Dust in Cities Worldwide

\begin{tabular}{llllllll}
\hline City & $\mathrm{Cr}$ & $\mathrm{Pb}$ & $\mathrm{Cu}$ & $\mathrm{Ni}$ & $\mathrm{Mn}$ & $\mathrm{Cd}$ & Ref. \\
\hline Bahrain & 144 & 697 & - & - & - & 72 & $(1)$ \\
Amman, Jordan & - & 236 & 177 & 88 & - & 1.7 & $(6)$ \\
Tokat, Turkey & 41 & 266 & 38 & 128 & 415 & 5.4 & $(7)$ \\
Luanda, Angola & 26 & 315 & 42 & 10 & 258 & 1.1 & $(8)$ \\
Istanbul, Turkey & - & $105-$ & $49-$ & & & & \\
& & 556 & 234 & 33 & - & 2.3 & $(18)$ \\
Sivas, Turkey & - & 197 & 84 & 68 & - & 2.6 & $(19)$ \\
Birmingham, UK & - & 48 & 467 & - & - & 1.6 & $(34)$ \\
Kayseri, Turkey & 72.8 & 166 & 66.7 & 57 & 274 & 10.1 & $(36)$ \\
Xi'an, P.R. China & 167 & 231 & 94.9 & - & 687 & - & $(37)$ \\
Islamabad, Pakistan & - & 104 & 52 & 23 & - & 5.0 & $(39)$ \\
London, UK & - & 1.03 & 155 & - & - & 3.5 & $(40)$ \\
Manchester, UK & - & 265 & 113 & - & - & - & $(41)$ \\
Denizli, Turkey & 75.0 & 145 & 147 & 86.2 & 158 & $<0.1$ & This \\
& & & & & & & work \\
\hline
\end{tabular}

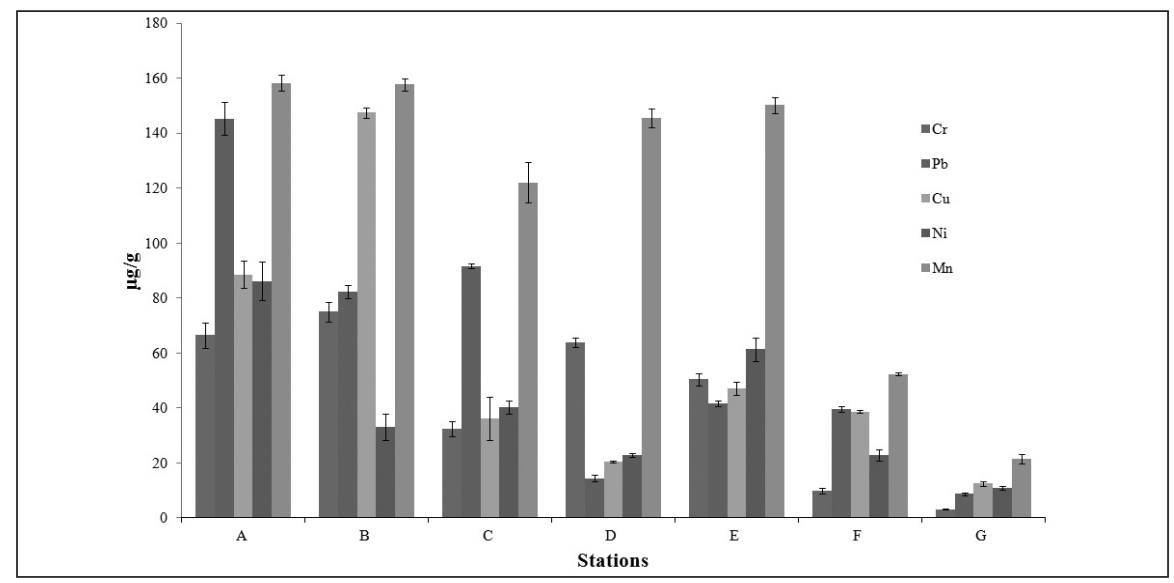

Fig. 1. The mean level of trace heavy metals in street dust samples from Denizli city center: A: Heavy traffic (N:10), B: Moderate traffic (N:10), C: Low traffic (N:9), D: Car parks (N:10), E: Health and hospital, centers (N:10), F: School gardens (N:10), G: Control sample (N:3). 
Figure 1 also shows that samples $\mathrm{A}, \mathrm{B}$, and $\mathrm{C}$ are $\mathrm{Pb}$-contaminated, $\mathrm{A}$ and $\mathrm{B}$ are $\mathrm{Cu}-$ contaminated, and $\mathrm{A}$ and $\mathrm{E}$ are Ni-contaminated. All were collected at high-level polluted areas, thus all exceeded the MAC. The mean level of the investigated ions in the control sample collected from one park, which has no traffic, is depicted in Figure 1. The concentrations of the analytes in all analyzed samples werefound to be higher than those in the control sample.

\section{Relation Between Metal Concentrations}

In order to establish the interelement relationship in road dust samples, the Pearson correlation coefficients were calculated. The correlations of the metals in the street dust samples of Denizli are given in Table V. All metals have a positive correlation. The maximum correlation value was 0.928 , which is between $\mathrm{Mn}$ and $\mathrm{Cr}$. The lowest value of the correlation coefficient was between $\mathrm{Ni}$ and $\mathrm{Cu}$ at 0.238. A moderate correlation coefficient was found between $\mathrm{Cu}$ and $\mathrm{Pb}$ (0.533) and between $\mathrm{Cu}$ and $\mathrm{Cr}$ (0.585). This may imply that $\mathrm{Cu}$ and $\mathrm{Pb}$ have somewhat similar sources, i.e., due to vehicular and industrial activities. The origin of $\mathrm{Cu}$ and $\mathrm{Cr}$ is also related to heavy traffic, which must come from exhaust fumes, engines, wear and tear of tires, leakage of oil from vehicles, and corrosion of batteries and metallic parts. The $\mathrm{Ni}-\mathrm{Cu}$

TABLE V

Pearson's Correlation Matrix Between the Concentration of Trace Metals in Dust Samples ( $r=95 \%)$

\begin{tabular}{|c|c|c|c|c|c|}
\hline Elements & $\mathrm{s} \mathrm{Cr}$ & $\mathrm{Pb}$ & $\mathrm{Cu}$ & $\mathrm{Ni}$ & Mn \\
\hline $\mathrm{Cr}$ & 1 & & & & \\
\hline $\mathrm{Pb}$ & 0.279 & 1 & & & \\
\hline $\mathrm{Cu}$ & 0.585 & 0.533 & 1 & & \\
\hline $\mathrm{Ni}$ & 0.345 & 0.731 & 0.238 & 1 & \\
\hline $\mathrm{Mn}$ & 0.928 & 0.337 & 0.434 & 0.509 & 1 \\
\hline
\end{tabular}
tration of the element in street dust, $B_{n}$ is the geochemical background value (Table III). The $\mathrm{I}_{\text {geo }}$ values for the analytes in street dust samples from Denizli are shown in Figure 2. The $I_{\text {geo }}$ represents the following: free of contamination $\left(\mathrm{I}_{\mathrm{geo}} \leq 0\right)$; low contamination $\left(0<\mathrm{I}_{\text {geo }} \leq 1\right)$; moderately contaminated $\left(1<\mathrm{I}_{\text {geo }} \leq 2\right)$; moderate to high contaminated $\left(2<\mathrm{I}_{\text {geo }} \leq 3\right)$; high level contamination $\left(3<\mathrm{I}_{\text {geo }} \leq 4\right)$; high to extremely high level contamination $\left(4<\mathrm{I}_{\mathrm{geo}} \leq 5\right)$, and extremely high level contamination $\left(\mathrm{I}_{\text {geo }} \leq 5\right)$ (43). Cr and Mn were found at lower levels, but moderate $\mathrm{Pb}, \mathrm{Cu}$, and $\mathrm{Ni}$ contamination was found in all samples. Cd was not found at contaminant levels. The plots in Figure 2 represent the contamination levels for all elements studied.

\section{CONCLUSION}

The present work studied the heavy metals concentrations in street dust of Denizli, Turkey. The highest metal values were found in heavy traffic sites, while the lowest concentrations of the metals were found in school gardens, hospitals, and health centers. The concentration ranges were $\mathrm{Cu}$ at 20.4-147.4 $\mathrm{Mg} \mathrm{g}^{-1}$, Cr at 9.9-75.0 $\mu \mathrm{g} \mathrm{g}^{-1}, \mathrm{Ni}$ at 22.8-86.2 $\mu \mathrm{g} \mathrm{g}^{-1}, \mathrm{~Pb}$ at $14.4-145.3 \mu \mathrm{g} \mathrm{g}^{-1}$, and $\mathrm{Mn}$ at 52.3-158.3 $\mu \mathrm{g} \mathrm{g}^{-1}$. The Cd content for all dust samples was below 0.1 $\mu \mathrm{g} \mathrm{g}^{-1}$. The mean concentrations of the studied metals follow the order of: $\mathrm{C}_{\mathrm{Mn}}>\mathrm{C}_{\mathrm{Cu}}>\mathrm{C}_{\mathrm{Pb}}>\mathrm{C}_{\mathrm{Ni}}>\mathrm{C}_{\mathrm{Cr}}>\mathrm{C}_{\mathrm{Cd}}$. The concentration of $\mathrm{Mn}$ in the dust of Denizli is comparatively high (average value is $131.0 \mu \mathrm{g} \mathrm{g}^{-1}$ ), since the main origin of $\mathrm{Mn}$ is from the geological material from middle Anatolia in addition to traffic. The trend of an increase in industrialization and traffic in Denizli center indicates the need for pollution control of the local environment. Furthermore, this study could help other researchers for comprehensive 
assessment of environmental quality, better city planning, and sustainable management of urban resources in all big cities in all countries.

\section{ACKNOWLEDGMENT}

The authors are grateful for the financial support of the Unit of the Scientific Research Projects of Pamukkale University, Denizli, Turkey.

Received May 9, 2015.

\section{REFERENCES}

1. M.S. Akhter and I.M. Madany, Water Air Soil Poll. 66, 111 (1993).

2. F.M. Howari, Y. Abu-Rukah and P.C. Goodell, Internatl. J. Environ. Poll. 22, 597 (2004).

3. O.A. Al-Khashman, Atmos. Environ. 38, 6803 (2004).

4. D. Hjortenkrans, B. Bergback and A. Haggerud, Environ. Monitor. Assessmt. 117, 85 (2006).

5. J. Yisa, O.J. Jacob and C.C. Onoyima, Am. J. Chem. 2, 34 (2012).

6. A.S. Al-Radady, B.E. Davies and M.J. French, Sci. Total. Environ. 145, 143 (1994).

7. M. Tuzen, J. Trace Microprobe Tech. 21,513 (2003).

8. L. Ferreira-Baptista and E. DeMiguel, Atmos. Environ. 39, 4501 (2005).

9. S.M.G. Al-Fatlawi and M. Al-Alwani, J. Mechanical Material Eng. 12, 660 (2012).

10. A.M Khairy, O.A. Barakat, R.A. Mostafa and L.T. Wade, Microchem. J. 97, 234 (2011).

11. A. Londonio, F. Fujiwara, R.F. Rebagliati and D. Gómez, Microchem. J. 105, 77 (2012).

12. R.A. Sutherland and C.A. Tolosa, Environ. Pollut. 110, 483 (2000).

13. O.J. Ogunsola, A.F. Oluwole, O.I. Asubiojo, H.B. Olaniyi, F.A. Akeredolu, O.A. Akanle, N.M. Spyrou, N.I. Ward and W. Ruck, Sci. Total. Environ. 147, 175 (1994).
14. M. Soylak, I. Narin, L. Elci and M. Dogan, Fresen. Environ. Bull. 9, 36 (2000).

15. X.D. Li, C.S. Poon and S.L. Pui, App. Geochem. 16, 1361 (2001).

16. O.A. Al-Khashman and R. Shawabkeh, Environ. Poll. 140, 387 (2006).

17. C. Pagotto, N. Rémy, M. Legret and P. Le Cloirec, Environ. Tech. 22, 307 (2001).

18. N. Sezgin, H.K. Ozcan, G. Demir, S. Nemlioglu and C. Bayat, Environ. Int. 29, 979 (2003).

19. A. Elik, Commun. Soil Sci. Plant Anal. 34, 145 (2003).

20. L. Han, G. Zhuang, S. Cheng, Y. Wang, and J. Li, Atmosph. Environ. 41, 7485 (2007).

21. H. Li, X. Qian, W. Hu, Y. Wang and H. Gao, Sci. Total Environ. 456, 212 (2013).

22. O. Turkoglu, S. Saracoglu, M. Soylak and L. Elci, Trace Elem. Electroly. 21, 4 (2004).

23. U.S. Environmental Protection Agency: Soil screening guidance: technical background document. Office of Solid Waste and Emergency Response (EPA/540/R95/128), (1996).

24. A.D.K. Banerjee, Environ. Pollut. 123, 95 (2003).

25. X.S. Luo, S. Yu and X.D. Li, Environ. Pollut. 159, 1317 (2011).

26. O. Turkoglu, S. Saracoglu and M. Soylak, Trace Elem. Electroly. 20, 225 (2003).

27. M. Soylak, L. Elci, S. Saracoglu and U. Divrikli, Asian J. Chem. 14, 135 (2002).

28. E.R. Christensen and V.P. Guinn, ASCE Environ. Eng. Div. J. 105, 165 (1979).

29. M. Soylak and L. Elci, J. Trace Microprobe Tech. 18, 397 (2000).

30. W. Wilcke, S. Muller, N. Kanchanakool and W. Zech. Geoderma 86, 211 (1998).

31. M. Ghaedi, K. Niknam, K. Taheri, H. Hosseinian and M. Soylak, Food Chem. Toxicol. 48, 891 (2010).
32. A. Vural, I. Narin, M.E. Erkan and M. Soylak, Environ. Monit. Assessmt. 139, 27-33 (2008).

33. S. Willers, L. Gerhardsson and T. Lundh, Respir. Med. 99, 1521 (2005).

34. S. Saracoglu, U. Divrikli, M. Soylak, L. Elci and M. Dogan, J. Trace Microprobe Tech. 21, 389 (2003).

35. C.Y. Zhou, M.K. Wong, L.L. Koh and Y.C. Wee, Environ. Monit. Assess. 44, 605 (1997).

36. U. Divrikli, M. Soylak, L. Elci and M. Dogan, J. Trace Microprobe Techn. 21, 351 (2003).

37. H. Yongming, D. Peixuan, C. Junji and E. Posmentier, Sci. Total Environ. 355, 176 (2006).

38. The Official Gazette of the Republic of Turkey; Regulation on controlling soil pollution, No. 25831, 31.05.2005.

39. Y. Faiz, M. Tufail, M.T. Javed, M.M. Chaudhry and N. Siddique, Microchem. J. 92, 186 (2009).

40. M.J.R. Schwar, J.S. Moorcroft, D.P.H. Laxen, M. Thompson and C. Armorgie, Sci. Total Environ. 68, 25 (1988).

41. D.J. Robertson, K.G. Taylor and S.R. Hoon, App. Geochem. 18, 269 (2003).

42. G. Muller, Geo. J. 2, 108 (1969).

43. B. Wei and L. Yang, Microchem. J. 94, 99 (2010). 